\title{
Macrozoobenthos as bioindicator of ecological status in Tanjung Pasir Coastal, Tangerang District, Banten Province, Indonesia
}

\author{
ASEP SAHIDIN ${ }^{1,2}$, ZAHIDAH $^{1}$, HETI HERAWATI ${ }^{1}$, YUSLI WARDIATNO ${ }^{3}$, ISDRADJAD SETYOBUDIANDI ${ }^{3}$, \\ RUHYAT PARTASASMITA ${ }^{4, \vartheta}$ \\ ${ }^{1}$ Department of Fisheries, Faculty of Fisheries and Marine Science, Universitas Padjadjaran. J1. Raya Bandung-Sumedang Km. 21, Jatinangor, \\ Sumedang 45363, West Java, Indonesia \\ ${ }^{2}$ Aquatic Resource Laboratory, Faculty of Fisheries and Marine Science, Universitas Padjadjaran. Jl. Raya Bandung-Sumedang Km. 21, Jatinangor, \\ Sumedang 45363, West Java, Indonesia \\ ${ }^{3}$ Department of Aquatic Resource Management, Faculty of Fisheries and Marine Science, Institut Pertanian Bogor. Darmaga Bogor 16680, West Java, \\ Indonesia \\ ${ }^{4}$ Department of Biology, Faculty of Mathematics and Natural Sciences, Universitas Padjadjaran. J1. Raya Bandung-Sumedang Km. 21, Jatinangor, \\ Sumedang 45363, West Java, Indonesia. Tel./fax.: +62-22-7796412, `email: rp2010rikkyo@gmail.com; ruhyat.partasasmita@unpad.ac.id
}

Manuscript received: 12 April 2018. Revision accepted: 22 May 2018.

\begin{abstract}
Sahidin A, Zahidah, Herawati H, Wardiatno Y, Setyobudiandi I, Partasasmita R. 2018. Macrozoobenthos as bioindicator of ecological status in Tanjung Pasir Coastal, Tangerang District, Banten Province, Indonesia. Biodiversitas 19: 1123-1129. The existence of macrozoobenthos organism allow for bioindicator of ecological status and detected water pollution in coastal environment with observing the response, diversity, and abundance. The one of biological method for water quality analysis is AZTI Marine Biotic Index (AMBI). This research aims to determine water quality status in Tanjung Pasir water coastal Tangerang, Banten. The research was conducted in April - August 2014 in Tanjung Pasir Coastal, Tanggerang, Banten with purposive sampling method and be forwarded with water pollution analysis with AZTI Marine Biotic Index (AMBI) model. The research showed 4.552 individual of macrozoobenthos found divided into 52 species with the average of diversity amount $634 \mathrm{ind} . / \mathrm{m}^{2}$ with dominated by bivalve species Nuculana bicuspidate $22.89 \%$, it is a bivalve an extreme species that can live in waters with very low oxygen concentrations and hight pollution. The result of AMBI (4.01 to 5.02) indicates water pollution in Tanjung Pasir Coastal classified in medium-heavy pollution and concentred in coastal zone. Polychaeta is a key bioindicator in the determination of water pollution and ecological status in Tanjung Pasir coastal.
\end{abstract}

Keywords: Bioindicator, ecological status, macrozoobenthos, pollution

\section{INTRODUCTION}

Macrozoobenthos is an organism that lives on the surface or in water sediment. Macrozoobenthos is the one of the most important organism in coastal and sea ecosystem (Dean 2008; Junardi and Wardoyo 2008; Shokat et al. 2010; Tabatabaie and Amiri 2010; Sharma et al. 2018), because it has a direct function in the nutrient cycle, pollutant metabolism and secondary productivity in water sediment (Kroncke and Reiss 2010; Tabatabaie and Amiri 2010, 2011). Macrozoobenthos also become one of the most important parts of water ecosystem food chain as food for demersal fish and some sea mammals (Sahidin and Yusli 2016). The existence of macrozoobenthos is widespread, each area has their community, depend on waters characteristic. Spatial distribution difference of macrozoobenthos is affected by depth, temperature, salinity, and substrate type (Shou et al. 2009; Gholizadeh et al. 2012).

Macrozoobenthos movement is very limited, and relative settle on a particular substrate, make macrozoobenthos more sensitive to environmental pressure as like water quality declamation and sediment (Manoharan et al. 2011; van Loon et al. 2015; Wardiatno et al. 2017). Physical, chemical and biological changes are the indicator of coastal water quality declamation (Sharma et al. 2018).
The changed of a physical compound and chemical compound also generate sediment quality declamation. Seawater biota which impacted by water and sediment quality declamation directly in coastal is macrozoobenthos. Declamation of species composition in coastal waters particularly infauna is a response from pollutant mater in sediment from anthropogenic activity. According to Gholizadeh et al. (2012), the spatial changed of macrozoobenthos community is dependent on the shape of sediment particle, organic matter, and dept. So that, macrozoobenthos always used to be a bioindicator for monitoring coastal water pollution (Dean 2008; Shokat et al. 2010; Subida et al. 2012; Sundaravaman et al. 2012; Wibowo et al. 2017; Sharma et al. 2018).

Approachment to determine water condition would be conducted with two methods, using biota response to environmental pressure, describe the water quality and environment condition and known as bioindicator (Prato et al. 2009; Ritter et al. 2009; Sundaravaman et al. 2012). Determining waters condition with a biological method is better than use physical-chemical methods because physicchemical methods only describe waters condition in shortterm (Junshum et al. 2008). The biological method could describe waters condition in long-term because this method will analyze biota response in pressure water (Carretero and Dauvin 2010; George et al. 2010). 
There are many researchers who study about estuarine or sea with macrozoobenthos as bioindicator with (richness, diversity, similarity, and domination) index (Junshum et al. 2018; Gandomy et al. 2011; Reizopoulou et al. 2014). One of the biological methods for water quality analysis is AZTI Marine Biotic Index (AMBI) which introduced by Bojan et al. (2012). AMBI is index calculation to determine waters status, pressure and pollution status based on biota response particularly for tolerance benthos, intolerance, and the diversity (Borja and Tunberg 2011), and also fully equipped by software to make calculation easier (Borja et al. 2012). AMBI method always used for some researcher in the world such as researcher from Atlantic Ocean and Mediterania (Carretero dan Dauvin 2010), eastern Florida coastal (Borja and Tunberg 2011), Brazil coastal (Valenca dan Santos 2012), Baltik ocean (Zettler et al. 2009), Atlantic ocean in North America (Riera and Carretero 2014), Caspia sea (Gandomy et al. 2011), Hindia ocean in North West (Bigot et al. 2008; Martin et al. 2011) and Asia (Sahidin et al. 2014).

Tanjung Pasir coastal belongs to the Tangerang coastal area of northern Banten province with various community activities around it (industry, fishery, housing and tourism) that have negative effects such as coastal erosion, pollution, and organic waste. So that, Tanjung Pasir coastal belongs to the one of the coasts of Indonesia with high level of vulnerability. Overflow that goes to Tanjung Pasir coastal not only organic material rich in nutrients also contains toxic materials (toxins) are harmful to aquatic biota. Based on the topography of the western coast of Tanjung Pasir bordering the eastern coast of Jakarta. Riyadi et al. (2012) declare that Jakarta coastal has a high level of pollution, so that on the West Tanjung Pasir coastal will get pollutant contamination from Jakarta coastal. In addition, the Tanjung Pasir coastal into the mouth of several major rivers like Cisadane river and Dadap river. The rivers flow will bring nutrient and pollutant into the coastal (Riyadi et al. 2012). There are many of research about ecology status and pollution in Jakarta bay since 1970-1990 which focus on seawater quality with physicochemical parameter, and be continued in 1990-2000, developing to biota and sediment, and in 2000- now focus on biomass and heavy metal (Wibowo et al. 2017).

However, in the coastal areas of Tanjung Pasir, areas adjacent to Jakarta still lack research directed to ecological status and pollution. Therefore, the determination of ecological status and contamination that is compared between instantaneous pollution (physical-chemical waters) and long-term pollution (biota response) becomes the basis for coastal resource management in Tanjung Pasir coastal.

\section{MATERIALS AND METHODS}

The research was conducted in Tanjung Pasir Coastal Waters, Tangerang District, Banten Province, Indonesia. Sample was taken from 22 stations (Table 1) and each location divided into three zonations (shore, middle, and sea) (Figure 1). Each station was taken three times of replication for macrozoobenthos and one replication for sediment analysis using Van Veen grab with wide aperture tool $0.04 \mathrm{~m}^{2}$. Sample filtered with modification filter for macrozoobenthos with mesh size $0.5 \mathrm{~mm}$ to separate between benthos and mud (substrate). Result of filtered put into sample bottle which stuck by label. Sample preserved with formalin $5 \%$ and put into the cool box and identified in laboratory. $\square$

In the laboratory, macrobenthos samples were observed using binocular microscopes for small size and magnifying glass (lup) for larger ones (Lizarralde and Pittaluga 2010). Identifying macrobenthos morphologically to the species level was conducted by using standard macrobenthos identification books (Fauchald 1977; Dharma 2005) and nomenclature writing following World Register of Marine Species (WoRMS: http://www.marinespecies.org/index.php). Organic carbon and sediment particle size (sand, mud, and clay) were analyzed using the "wet sieving" method (Reizopoulou et al. 2014). Water temperature measurements using standard thermometer and brightness are measured with a Secchi disk. Salinity was measured by using a refractometer, and the $\mathrm{pH}$ was measured by $\mathrm{pH}$ meters. Measurement of depth of waters with the aid of scaled ropes and suspended solids was measured by filtration method. Dissolved oxygen (DO) is estimated by modification of the winkler method. The water nutrients are first put into a polyethylene bottle and collected in the icebox to be brought to the laboratory. The water sample was filtered using a Millipore strainer to analyze the nitrates, nitrites, soluble phosphates with the aid of the spectrophotometer. While water used to measure biological oxygen demand (BOD5) was inputted into dark glass bottles and analyzed by a modification of the Winkler method (Lizarralde and Pittaluga 2010; Reizopoulou et al. 2014).

Ecological and pollution status analysis based on macrozoobenthos using AZTI Marine Biotic Index (AMBI) (Borja et al. 2012; Carretero dan Dauvin 2010). AMBI analysis was started with the calculation of diversity for each species in each station. The species were divided by five Ecological Group (EG) there as (i) EGI: Macrozoobenthos species with very sensitive to organic matter composition. (ii) EGII: Macrozoobenthos species with not affected by organic matter composition with low concentration. (iii) EGIII: Macrozoobenthos species with tolerant from more organic matter composition. (iv) EGIV: Opportunistic macrozoobenthos species grade II. (v) EGV: Opportunistic macrozoobenthos species grade I. $\square$

$A M B I=\frac{\left(0 x \% E G_{1}\right)+\left(1.5 x \% E G_{2}\right)+\left(3 x \% E G_{3}\right)+\left(4.5 x \% E G_{4}\right)+\left(6 x \% E G_{5}\right)}{100}$

Based on the divided group, AMBI formula calculated and classified based on AMBI (biotic coefficient) in Table 2.

Table 1. Station in different zonation

\begin{tabular}{ll}
\hline Zonation & Station \\
\hline Coastal zone (cz) & T1, T2, T3, T10, T11, T12, T16, T17, T18 \\
Middle zone (mz) & T4, T5, T6, T13, T14, T15, T19, T20 \\
Sea zone (sz) & T7, T8, T9, T21, T22 \\
\hline
\end{tabular}

Note: $\mathrm{T}=$ Tanjung Pasir Coastal station 

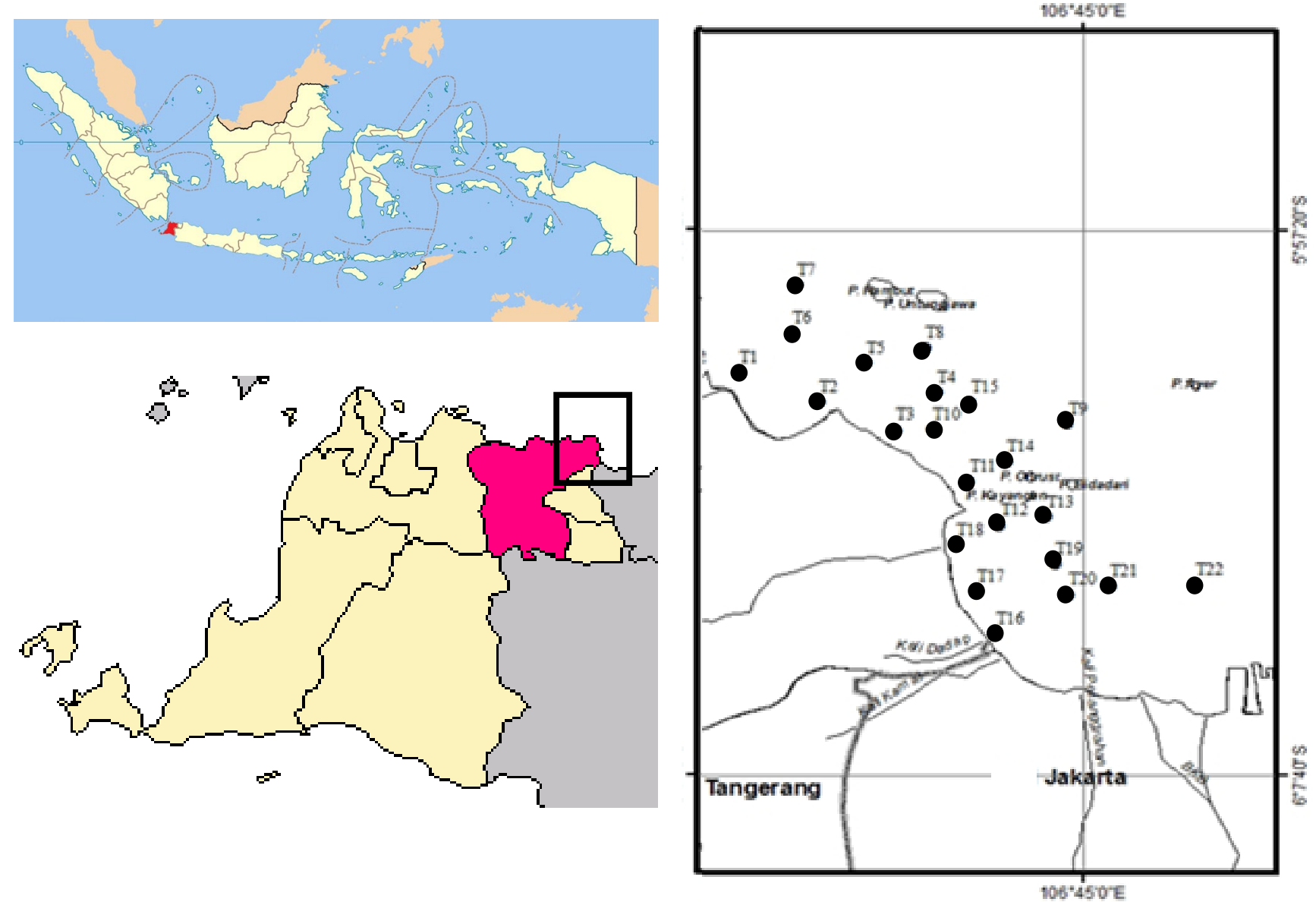

Figure 1. GIS location of sampling sites in Tanjung Pasir Coastal Waters, Tangerang District, Banten Province, Indonesia

Table 2. Ecological group classification of macrozoobenthos on analysis value of AMBI and BI (Biotic Index) based on Borja et al. (2012) and Carretero dan Dauvin (2010)

\begin{tabular}{lcllll}
\hline AMBI & Biotic index & Domination EG & Pollution status & Health of benthos community & Ecology status \\
\hline $0.0<\mathrm{BC} \leq 0.2$ & 0 & Egi & Not polluted & Normal & Very good \\
$0.2<\mathrm{BC} \leq 1.2$ & 1 & Egi & Not polluted & Increase & Very good \\
$1.2<\mathrm{BC} \leq 3.3$ & 2 & Egiii & Easy polluted & Not balance & Good \\
$3.3<\mathrm{BC} \leq 4.3$ & 3 & Egiii & Medium polluted & Transition to polluted & Medium \\
$4.3<\mathrm{BC} \leq 5.0$ & 4 & Egiv-V & Medium polluted & Polluted & Bad \\
$5.0<\mathrm{BC} \leq 5.5$ & 5 & Egiv-V & Heavy polluted & Transition to heavy polluted & Bad \\
$5.5<\mathrm{BC} \leq 6.0$ & 6 & Egv & Heavy polluted & Heavy polluted & Very bad \\
Azoic & 7 & Azoic & Very heavy polluted & Azoic & Very bad
\end{tabular}

Note: BC: biotic coefficient, EG: ecological group

\section{RESULTS AND DISCUSSION}

\section{Water and sediment quality parameters}

The result of water quality in every sample zonation are presented in Table 3. Water quality as temperature parameters, $\mathrm{pH}$, biochemical oxygen demand (BOD) and salinity found between zonation with values was not significantly different. As for parameter dissolved oxygen (DO) and turbidity seen significant difference between coastal zonation with two other zonation's. Dissolved oxygen in coastal zonation was found with a very low value of $0.5 \mathrm{mg} / \mathrm{L}$, while the turbidity in coastal zonation was found with the highest value of $7.2 \mathrm{mg} / \mathrm{L}$. Seen from sediment size composition, sand presentation decreased toward sea (sand presentation at $\mathrm{cz}=44.28 \%, \mathrm{mz}=$ $27.23 \%$ and $\mathrm{sz}=17.97 \%$ ), vice versa increasing muddy (mud presentation at $\mathrm{cz}=55.6 \%, \mathrm{mz}=72 \%$ and $\mathrm{sz}=$ $82.20 \%$ ). 
Table 3. Physical quality and chemical coastal waters of Tanjung Pasir Coastal Waters, Tangerang District, Banten Province, Indonesia

\begin{tabular}{|c|c|c|c|c|c|c|c|}
\hline \multirow{2}{*}{ Parameters } & \multirow{2}{*}{ Unit } & \multicolumn{2}{|c|}{ Coastal zone } & \multicolumn{2}{|c|}{ Middle zone } & \multicolumn{2}{|l|}{ Sea zone } \\
\hline & & $\mathbf{x}$ & $\mathbf{r}$ & $\mathbf{x}$ & $\mathbf{r}$ & $\mathbf{x}$ & $\mathbf{r}$ \\
\hline \multicolumn{8}{|l|}{ Water quality } \\
\hline Temperature & ${ }^{0} \mathrm{C}$ & 31.0 & $30.4-31.8$ & 30.8 & $30.3-31.4$ & 30.9 & $30.1-31.5$ \\
\hline $\mathrm{pH}$ & & 8.2 & $7.1-8.7$ & 8.4 & $7.1-8.4$ & 8.3 & $7.9-8.5$ \\
\hline Dissolved Oxygen & $\mathrm{mg} / \mathrm{L}$ & 7.1 & $0.5-10.1$ & 8.3 & $7.6-9.1$ & 9.0 & $6.8-10.6$ \\
\hline Biochemical Oxygen Demand & $\mathrm{mg} / \mathrm{L}$ & 3.6 & $0.7-6.9$ & 2.8 & $1.0-6.4$ & 2.2 & $1.5-3.0$ \\
\hline Salinity & $\%$ & 27.4 & $12.2-30.3$ & 29.2 & $24.7-30.3$ & 29.5 & $28.5-30.3$ \\
\hline Turbidity & NTU & 7.2 & $0.5-21.6$ & 2.2 & $0.4-11.4$ & 1,6 & $0.5-2.9$ \\
\hline \multicolumn{8}{|l|}{ Sediment quality } \\
\hline Sand & $\%$ & 44.28 & $37.6-53.7$ & 27.23 & $18.1-54,5$ & 17.97 & $7.9-28.1$ \\
\hline Mud & $\%$ & 55.58 & $46.3-63.6$ & 72.72 & $58.1-90,1$ & 82.20 & $72.3-92.1$ \\
\hline C-Organic & $\%$ & 1.78 & $1,31-2,50$ & 1.65 & $1.52-2.50$ & 1.65 & $1.54-1.76$ \\
\hline
\end{tabular}

Note: $x$ : average, r: range

\section{Composition and abundance of macrozoobenthos}

The composition and abundance of macrozoobenthos are one of the characteristics of the community structure. Based on the results of research, macrozoobenthos found as many as 52 species were divided into 14 classes. The highest species composition was found in 17 Polychaeta classes followed by Bivalvia class of 10 species, 4 species of gastropods, 6 species of crustaceans, and other classes. The total number of macrozoobenthos total specimens were 4552 specimens dominated by bivalve class followed by Polychaeta. The highest number of specimens found in the bivalve class reached $71 \%$ of the total number of macrozoobenthos found, followed by the Polychaeta class and clitellate class (Figure 2). The bivalve class was dominated by Nuculana bicuspidata $22.89 \%$ of the total number of bivalve individuals found. Nuculana bicuspidata were found in T12, T16 and T17 stations. The stations adjacent to the mouth of the river (Figure 3) were T2, T12, T16, T18 stations found high density of macrozoobenthos and high deviation values, which means that macrozoobenthos at the station was very dynamic or volatile in a short span of time.

\section{Discussion}

Total species of macrozoobenthos were found in 52 species divided into 14 classes. The Polychaeta class (17 species) was found with the largest number of species Polychaeta deposit feeder (20 species), followed by Bivalvia classes and other classes (Table 4). Shou et al. (2009) state that Polychaeta dominates the community of infauna benthos and the amount in nature reaches $80 \%$ of the total macrozoobenthos community. The research location is dominated by mud substrate. The muddy bottom of the waters is the preferred habitat for polychaete to grow and reproduce (Sundaravarman et al. 2012), since the organic matter as the main food polychaete deposit feeder is easily settled and binds to the mud substrate (Golizhadeh et al. 2012; Junardi and Wardoyo 2008). But in this study, the highest total density was not occupied by the Polychaeta class but Bivalvia namely Codakia puncata, Tellina palatum and Tellina timorensis. These three biotas are small-sized bivalves and reproduce with external fertilization with very high egg fecundity and are concentrated in one place.

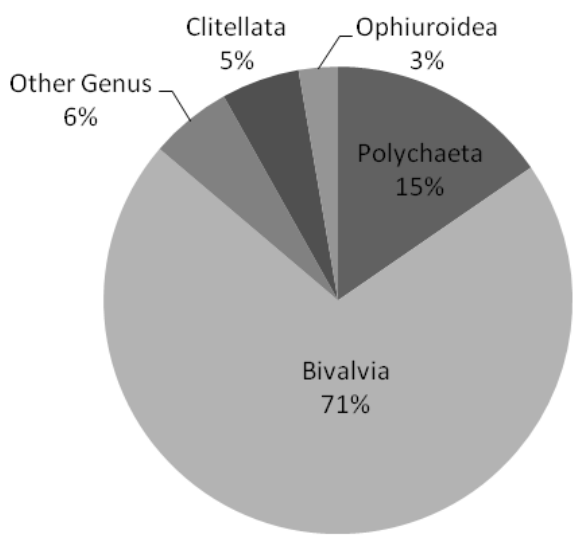

Figure 2. Macrobenthos composition in Tanjung Pasir Coastal Waters, Tangerang District, Banten Province, Indonesia

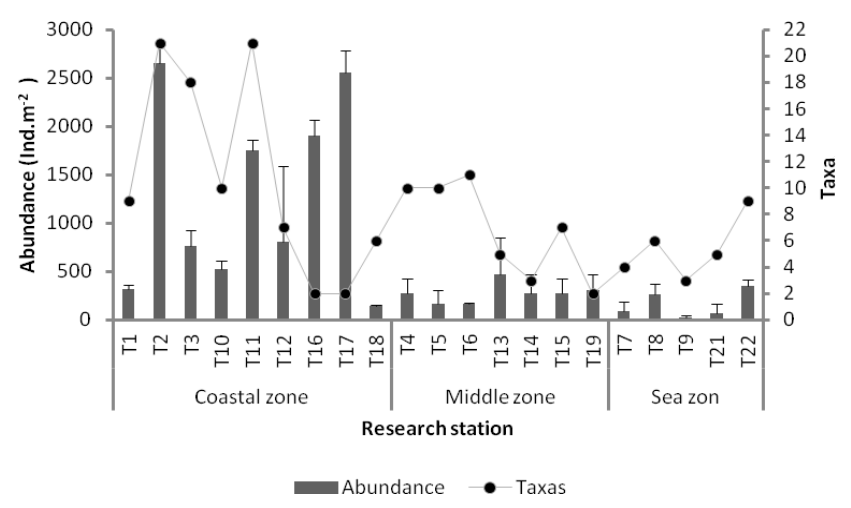

Figure 3. Abundance and taxa of macrozoobenthos in Tanjung Pasir Coastal Waters, Tangerang District, Banten Province, Indonesia $\square$ 
Table 4. Composition ecological group of macrozoobenthos in Tanjung Pasir Coastal Waters, Tangerang District, Banten Province, Indonesia $\square$

\begin{tabular}{|c|c|c|c|c|}
\hline \multirow{2}{*}{$\operatorname{Taxa} \square$} & \multicolumn{3}{|c|}{ Tangerang coastal } & \multirow{2}{*}{$\begin{array}{l}\text { Ecol. } \\
\text { group* }\end{array}$} \\
\hline & cz & $\mathbf{m z}$ & SZ & \\
\hline \multicolumn{5}{|l|}{ Polychaeta } \\
\hline Aphrodate aculeata & + & - & - & I \\
\hline Arenicola marina & + & - & - & III \\
\hline Capitella capitata & + & - & - & $\mathrm{V}$ \\
\hline Exogone naidina & - & + & - & II \\
\hline Glycera capitata & + & + & + & II \\
\hline Melinna cristata & + & - & - & III \\
\hline Nephtys caeca & + & - & - & II \\
\hline Nereis fucata & + & + & + & III \\
\hline Ophryotrocha puerilis & + & + & + & IV \\
\hline Orbinia sp. & + & - & - & I \\
\hline Petta pusilla & - & + & - & I \\
\hline Platynereis dumerilii & + & - & - & III \\
\hline Polyphysia crassa & + & - & - & III \\
\hline Rhodine loveni & + & - & - & II \\
\hline Scalibregma inflatum & + & - & - & III \\
\hline Sternaspis scutata & + & - & - & III \\
\hline Syllis gracilis & + & - & - & II \\
\hline \multicolumn{5}{|l|}{ Bivalvia } \\
\hline Brachidontes granulatus & + & - & - & II \\
\hline Cardium sp. & - & + & - & III \\
\hline Codakia punctata & + & + & + & I \\
\hline Ensis ensis & + & - & - & I \\
\hline Perna viridis & - & + & - & - \\
\hline Pharella javanica & + & - & - & I \\
\hline Tellina palatum & + & + & + & I \\
\hline Tellina sp. & - & - & + & I \\
\hline Tellina timorensis & + & + & + & I \\
\hline Nuculana bicuspidata & + & + & + & II \\
\hline \multicolumn{5}{|l|}{ Gastropoda } \\
\hline Nassarius liversen & + & - & - & II \\
\hline Nassarius stolatus & + & - & - & II \\
\hline Tetraphora princeps & + & - & - & - \\
\hline \multirow{2}{*}{\multicolumn{5}{|c|}{ Crustacea }} \\
\hline & & & & \\
\hline Apseudes coriolis & - & + & - & III \\
\hline Cancer pagurus & + & + & + & III \\
\hline Leucosia $\mathrm{sp}$. & - & + & - & - \\
\hline Pasiphaea sp. & + & - & - & II \\
\hline Pontophilus aracilis & + & - & - & I \\
\hline Xantho pilipes & + & + & + & I \\
\hline \multicolumn{5}{|l|}{ Anopla } \\
\hline Cerebratulus fuscus & + & - & - & III \\
\hline Micrura purpurea & - & - & + & I \\
\hline Psammamphiporus elongatus & + & - & - & II \\
\hline Tubulanus annulatus & + & + & - & II \\
\hline \multicolumn{5}{|l|}{ Enopla } \\
\hline Oerstedia dorsalis & + & + & - & III \\
\hline \multirow{2}{*}{\multicolumn{5}{|c|}{ Echinoidea }} \\
\hline & & & & \\
\hline Brissopsis pasifica & - & - & + & I \\
\hline \multicolumn{5}{|l|}{ Clitellata } \\
\hline Clitellio arenarius & + & + & + & V \\
\hline Pontobdella muricata & + & + & - & - \\
\hline \multicolumn{5}{|l|}{ Sipunculidea } \\
\hline Phascolion strombus & + & - & - & I \\
\hline \multicolumn{5}{|l|}{ Asteroidea } \\
\hline Astropecten indicus & + & - & - & I \\
\hline Ophiuroidea & & & & \\
\hline Amphiura chiajei & + & + & + & II \\
\hline Echiuroidea & & & & \\
\hline Echiura sp. & - & - & + & II \\
\hline Anthozoa & & & & \\
\hline Metridium senile & + & - & - & I \\
\hline Brachiopoda & & & & \\
\hline Linguila unguis & + & - & + & I \\
\hline
\end{tabular}

Note: + : present, - : not present, cz:coastal zone, mz: middle zone, sz: sea zone. * Borja et al. $(2000,2012)$.
Bray Curtis similarity analysis results from 22 stations formed four different groups. T2, T12, T17 and T19 stations each station form one group, the other stations form one other group (Figure 4). T2 station found Melinna cristata with the highest density, followed by Ophryotrocha puerilis, Syllis gracilis and Travesia forbesii also dominated the station. T17 stations found Tellina timorensis and Nuculana bicuspidata with the highest density compared to other stations, while Perna viridis and Tellina palatum were found to be concentrated at T19 stations. This grouping difference is possibly due to differences in pollution levels and substrate texture differences that will decrease or increase the number of types and densities of macrozoobenthos. The type of intolerant and facultative group will disappear as the Polychaeta class is not resistant to the low DO, and the dominant tolerant group appears to be the type of Nuculana bicuspidata bivalvia class that is tolerant to the low DO (Sahidin et al. 2014).

Coastal waters analysis can be seen vertically (perpendicular from the coast towards the sea) and horizontal (along with the coast). Tanjung Pasir, which borders the Bay of Jakarta, is heavily influenced by the pollution inputs of the Cisadane River and the overflowing of the bay of Jakarta carrying a current range of AMBI values (4.01-5.02) with moderate to severe pollution levels and moderately-categorized ecological status (Table 5). Riyadi et al. (2012) state that Coastal Jakarta has a high level of pollution, so that on the eastern coast of Tanjung Pasir will get pollutant contamination from Jakarta Coastal. Overflow that goes to the Coastal Tangerang not only organic material rich in nutrients also contains toxic materials (toxins) that are harmful to aquatic biota.

The coastal waters status of Tanjung Pasir was vertically seen towards the sea the smaller the AMBI value. This means that the lower the sea level the disturbance is smaller and the water status based on the benthic biota the better. It is possible that there are organic materials and macrozoobenthic food sources. Spatial distribution of benthic organisms is influenced by aquatic organic matter (Golizhadeh et al. 2012; Martin et al. 2011; George et al. 2010). In addition, the dominance of the sand substrate will decrease the content of organic matter in the sediments, thereby decreasing the presence of macrozoobenthic biota in both abundance and type and will ultimately affect ecological status (Zetler et al. 2009). Organic materials are sedimented into the substrate, the farther away from coastal zonation the less organic matter is sedimented (Ansari et al. 2014), so the macrozoobenthos food is reduced and has an effect on decreasing the number of types and densities of macrozoobenthos. This decrease of macrozoobenthos is possible because the decreasing of marine status at sea zonation based on AMBI value.

Nuculana bicuspidate Determination of water quality status based on AMBI result (4.01 - 5.02), increasingly the water quality with avoiding of shore with heavy pollution in the coastal zone (cz), medium in middle zone (cz), and middle in sea zone (sz). Bivalve species (Nuculana bicuspidate) was dominated by $22.89 \%$ from all bivalve in result. Nuculana bicuspidate is an extreme species that can live in waters with very low oxygen concentrations and high pollution. 


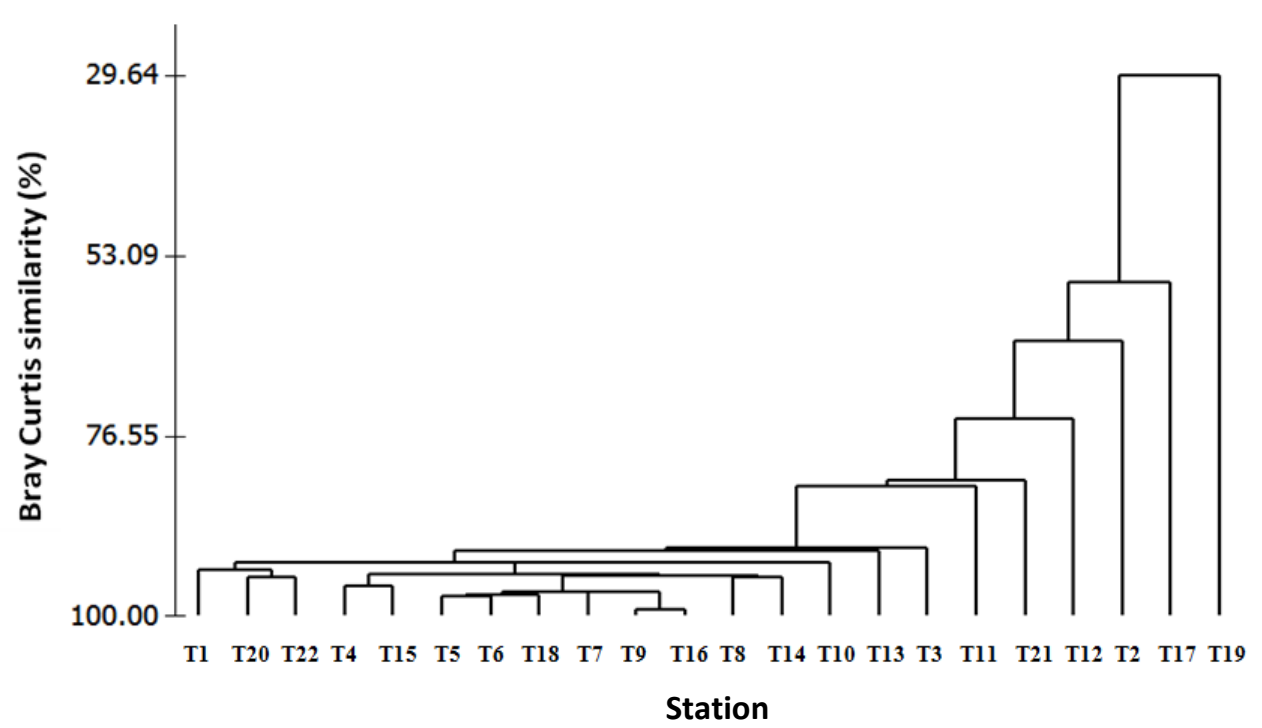

Figure 4. Similarity analysis of macrobenthos in Tanjung Pasir Coastal Waters, Tangerang District, Banten Province, Indonesia $\square$

Table 5. Presentation ecological group, AMBI value and pollution status in Tanjungg Pasir Coastal Waters, Tangerang District, Banten Province, Indonesia

\begin{tabular}{lccccccccc}
\hline \multirow{2}{*}{ Zone } & \multicolumn{4}{c}{ Group ecology (GE) (\%) } & \multicolumn{2}{c}{ Pollution status } & \multicolumn{2}{c}{ Ecological status } \\
& I & II & III & IV & V & AMBI & Status & BI & Level of disturbance \\
\hline $\mathrm{cz}$ & 2.6 & 4.7 & 8.2 & 24.7 & 59.8 & 5.02 & Heavy polluted & 5 & Disturbed \\
$\mathrm{mz}$ & 8.7 & 5 & 41 & 16.3 & 29 & 4.15 & Medium polluted & 4 & Medium disturbed \\
$\mathrm{sz}$ & 12.7 & 6.4 & 33.6 & 31.8 & 15.6 & 4.01 & Medium polluted & 4 & Medium disturbed \\
\hline
\end{tabular}

Note: cz:coastal zone, mz:middle zone, sz:sea zone, BI: Biotic index

\section{ACKNOWLEDGEMENTS}

The research funding is secured by Prof. Yusli Wardiatno. We are grateful to all of the colleagues who have assisted in collecting field data. This research was supported by a Directorate General of Higher Education graduate Fellowship (Postgraduate program), Indonesian Ministry of Research, Technology and Higher Education. This paper is part of the thesis in Department of Aquatic Resource Management, Faculty of Fisheries and Marine Science, Bogor Agricultural University, West Java, Indonesia

\section{REFERENCES}

Ansari ZA, Ingole BS, Abidi AH. 2014. Organic enrichment and benthic fauna-some ecological consideration. J Geo-Mar Sci 43 (2): 554-560.

Bigot L, Gremare A, Amouroux JM, Frouin P, Maire O, Gaertner JC. 2008. Assessment of the ecological quality status of soft-bottoms in Reunion Island (tropical Southwest Indian Ocean) using AZTI marine biotic indices. Mar Pollut Bull 56 (4): 704-722.

Borja A, Madel J, Mauxika I. 2012. Instructions for the use of the AMBI index software (Version 5.0). Revista de Investigacion Marine, AZTITecnalia 19 (3): 71-82.
Borja A, Tunberg BG. 2011. Assessing benthic health in stressed subtropical estuaries, eastern Florida, USA using AMBI and MAMBI. Ecol Indic 11 (2): 295-303

Carretero JADLO, Dauvin JC. 2010. A comparison of two biotic indices, $\mathrm{AMBI}$ and $\mathrm{BOPA} / \mathrm{BO} 2 \mathrm{~A}$, for assessing the ecological quality status (EcoQS) of benthic macroinvertebrates. Trans Waters Bull 4 (1): 1224. $\square$

Dean HK. 2008. The use of polychaetes (Annelida) as indicator species of marine pollution: a review Int J Trop Biol 56 (4): 11-38.

Dharma B. 2005. Recent \& fossil Indonesian shells. Hockenheim, Germany: Conch Books. $\square$

Fauchald K. 1977. The polychaete worms: Definition and keys to other, families and genera. Nature History Museum of Los Angeles Country. California.

Gandomy Y, Shadi A, Savari A. 2011. Classification of Gomishan lagoon (Caspian sea, Iran) by using the coastal and marine ecological classification standard (CMECS). Middle-East J Sci Res 8 (3): 611615. $\square$

George ADI, Abowei JFN, Alfred-Ockiya JF. 2010. The Distribution, abundance, and seasonality of benthic macroinvertebrate in Okpoka creek sediments, Niger Delta, Nigeria. Res J Appl Sci Eng Technol 2 (1): 11-18

Gholizadeh M, Yahya A, Talib A, Ahmad O. 2012. Effects of environmental factors on polychaete assemblage in Penang National Park, Malaysia. Word Academy of Sci Eng Technol J 6 (12): 752755.

Junardi, Wardoyo ERP. 2008. Community structure and substrate characteristic of marine worm (polychaete) in mangrove coastal water Peniti, West Kalimantan. Biodiversitas 9 (3): 213-216. 
Junshum P, Choonluchanon S, Traichaiyaporn S. 2008. Biological indies for classification of water quality around Mae Moh power plant Thailand. Mj Intl J Sci Tech 2 (1): 24-36.

Kroncke I, Reiss H. 2010. Influence of macrofauna long-term natura variability on benthic indices used in ecological quality assessment. Mar Pollut Bull 60 (1): 58-68.

Lizarralde Z, Pittaluga S. 2010. Distribution and temporal variation of the benthic fauna in the tidal flat of the Rio Gallegos estuary, Patagonia, Argentina. Thalassa 27 (1):9-20. $\square$

Manoharan J, Varadharajan D, Thilagavathi B, Priyadharsini S. 2011 Biodiversity and abundance of benthos along the South East Coast of India. Adv App Sci Res 2(6): 554-562.

Martin GD, Nisha PA, Balachandran KK, Madhu NV, Nair M, Shaiju P, Joseph T, Srinivas K, Gupta GVM. 2011. Eutrophication-induced changes in benthic community structure of a flow-restricted tropica estuary (Cochin backwaters), India Environ Monit Assess 176 (1): $427-438 \square$

Prato S, Morgana JG, La Valle P, Finoia MG, Lattanzi L, Nicoletti L, Ardizzone GD, Lzzo G. 2009. Application of biotic and taxonomic distinctness indices in assessing the ecological quality status of two coastal lakes: Gaprolace and Foglino lakes (Central Italy). Ecol Indic 9 (3): 568-583.

Reizopoulou S, Simboura N, Sigala K, Barbone E, Aleffi F, Kaisakis G, Rositi I, Basset A, Nicolaidou A. 2014. Assessment of the ecological status of the Mediterranean coastal lagoons using macroinvertebrates. Comparison of the most commonly used methods. Medit Mar Sci 15 (3): 602-612

Riera R, Carretero JADLO. 2014. Response of benthic opportunistic polychaetes and amphipods index to different perturbations in coastal oligotrophic areas (Canary archipelago, North East Atlantic Ocean). Mar Ecol 35 (3): 354-366.

Ritter KJ, Huff DD, Oakden JM, Thompson B, Velarde RG, Cadien DB, Ranasinghe JA, Weisberg SB, Smith RW, Montagne DE. 2009. Calibration and evaluation of five indicators of benthic community condition in two California bay and estuary habitats. Mar Pollut Bull 59 (3): 5-13.

Riyadi AS, Itai T, Isobe T, Ilyas M, Sudaryanto A, Setiawan I, Tahahash S. 2012. Spatial profile of trace elements in marine sediments from Jakarta Bay, Indonesia. Interdisciplinary Studies on Environmental Chemistry-Environmental Pollution and Ecotoxicology, Interdisciplinary Studies on Environmental Chemistry 6 (1): 141-150.

Sahidin A, Isdradjad S, Yusli W. 2014. Macrozoobenthos community structures of Tangerang coastal water, Banten. Depik. 3 (3): 226233. $\square$

Sahidin A, Yusli W. 2016. Spatial distribution of Polychaete at Tangerang coastal water, Banten Province. J Fish Mar 6 (2): 83-94. [Indonesian]
Sharma SD, Behera RR, Mohapatra U, Panda CR, Nayak L. 2018. Effect of estuarine effluents on benthic faunal communities in relation to tidal dynamics of Dhamra estuary. J Pharm Life Sci 4 (2): 127-134

Shokat P, Nabavil SMB, Savari1 A, Kochanian P. 2010. Ecological quality of Bahrekan coast, by using biotic indices and benthic communities. Transit. Waters Bull 4 (1): 25-34

Shou L, Huang Y, Zeng J, Goa A, Liao Y, Chen Q. 2009. Seasonal changes of macrobenthos distribution and diversity in Zhoushan sea area. Aquatic ecosystem health and management. 12 (1): 110-115.

Subida MD, Drake P, Jordana E, Mavrič B, Pinedo S, Simboura N, Torres J, Salas F. 2012. Response of different biotic indices to gradients of organic enrichment in Mediterranean coastal waters: implications of non-monotonic responses of diversity measures. Ecol Indic 19 (1): 106-107

Sundaravarman K, Varadharajan D, Babu A, Saravanakumar A, Vijayalakshmi S, Balasubramania T. 2012. A Study of marine benthic fauna with special reference to the environmental parameters, South East Coastal of India Intl J Pharm Biol Arch 3 (5): 1157-1169.

Tabatabaie T, Amiri F. 2010. The impact of industrial pollution on macrobenthic fauna communities. African J Environ Sci Technol 4 (9):547-557

Tabatabaie T, Amiri F. 2011. Evaluation of the impact of industrial sewage pollution on marine benthic communities. Journal of Water Supply: Res Technol-AQUA 60 (6): 364-374.

Valenca APMC, Santos PJP. 2012. Macrobenthic community for assessment of estuarine health in tropical areas (Northeast, Brazil): Review of macrofauna classification in ecological groups and application of AZTI marine biotic index. Mar Pollut Bull 64 (9): 1809-1820.

van Loon WMGM, Boon AR, Gittenberger A, Walvoort DJJ, Lavaleye M, Duineveld GCA, Verschoor AJ. 2015. Application of the benthic ecosystem quality Index 2 to benthos in Dutch transitional and coastal waters. J Sea Res 103 (1): 1-13.

Wardiatno Y, Qonita Y, Mursalin, Zulmi R, Effendi H, Krisanti M, Mashar A, Hariyadi S, Hakim AA, Sahidin A, Widigdo B, Nursiyamah S. 2017. Determining ecological status of two coastal waters in Western Java using macrozoobenthic community: A comparison between North Part and South Part. IOP Conf Ser: Earth Environ Sci 54 (1): 01207

Wibowo DN, Setijanto, Santoso S. 2017. Short communication: benthic macroinvertebrate diversity as biomonitoring of organic pollutions of river ecosystems in Central Java, Indonesia. Biodiversitas 18 (2): 671676.

Zetler ML, Ralf B, Falk P. 2009. Macrozoobenthos diversity in an oxygen minimum zone off northern Namibia. Mar Biol 156 (9): 1949-1961 